\title{
PRELIMINARY DIAGNOSES OF NEW MAMMALS FROM THE MEXICAN BORDER OF THE UNITED STATES. ${ }^{1}$
}

\author{
By Edgar A. Mearis, M. D.
}

IN THE collection of mammals made in connection with the recent resurvey of the boundary line between Mexico and the United States, are several which appear to be new to science. In view of the probable delay in issuing the complete report on these collections, it seems desirable that the new forms should be briefly described in advance.

\section{SPERMOPHILUS MEXICANUS PARVIDENS, new subspecies.}

RIO GRANDE SPERMOPHILE.

Erxleben's "Sciurus mexicanus" was based on Fernandez's description of his Tlamototli, and on Seba's "Sciurus rarissimus, ex Nova Hispana, tcriis albis." No locality was assigned in the inadequate description of Erxleben, but Lichtenstein, about 1830, accurately described and figured the species, from a specimen collected by Herr F. Deppe, in July, 1826, in the neighborhood of Toluca, Mexico. We can therefore fix the type locality of Spermophilus mexicanus as Toluca, Mexico.

Comparing six specimens of this species, from Kinney County, Texas, with an adult male-practically a topo-type of S. mexicanus-from Tlalpan, Mexico, lent me by Dr. C. Hart Merriam, who kindly furnished its measurements, taken in the flesh by the collector, ${ }^{2}$ the Texas specimens prove to be smaller, less yellowish and paler, with distinctive cranial and dental characters.

Type.-No. 63073, U.S.N.M. (Coll. International Boundary Commission). Adult male, from Fort Clark, Kinney County, Texas. Collected by Dr. Mearns, March 21, 1893. Original number, 2312.

Description of type.-Smaller than S. mexicanus; pattern similar; colors paler, with under parts white, not washed with yellowish brown; tail bushier, its hairs with two instead of three black annuli, and gray-

${ }^{1}$ This is the second of a proposed series of papers giving preliminary descriptions of the new mammals collected on the recent survey of the Mexican boundary.

Collected by E. W. Nelson, December 2. 1892. Length, $335 \mathrm{~mm}$; tail vertebræ, 148; hind foot, 50 . 
ish instead of yellowish tips; ground-color of dorsum yellowish broccoli brown, instead of tawny olive. Length, measured from nose to end of caudal vertebræ, $325 \mathrm{~mm}$; t tail vertebræ, 130 ; hind foot, 44 . The dentition is relatively lighter than in mexicanus (typica), the ratio of the length of the upper tooth-row to the basi-cranial axis being, in the two forms, as 5 to 6 . The skull of mexicanus is relatively high and narrow, with less spreading postorbital processes. The cranial measurements of the two specimens compared are as follows: Total length, 48-43 mm. (according to Hensel, 38-34.8); zygomatic breadth, 27-25; length of upper tooth-row, 10.5-8; height of skull, 15-13; across postorbitals, 18-17.5; between orbits, 10.2-8.2; basi-cranial axis (combined lengths of the basi-occipital and basi-sphenoid bones), 14.5-13.3.

\section{SPERMOPHILUS HARRISI SAXICOLUS, new subspecies.}

ROCK SPERMOPHILE.

Type.-No. 59869, U.S.N.M. (Coll. International Boundary Commission). Adult female, from Tinajas Altas, Gila Mountains, Yuma County, Arizona. Collected by Dr. E. A. Mearns and F. X. Holzner, February 17, 1894. Original number, 2983. Contained six large fœtuses.

Description of type.-Similar to S. harrisi, but much paler, with a longer tail. Length, $245 \mathrm{~mm}$; tail vertebræ, 93; ear from crown, 5; hind foot, 40 .

This is a long-tailed, pallid, desert race, inhabiting bare granite ranges of mountains, extending in a southeasterly direction from the Gila River, in southwestern Arizona (Yuma County), into western Sonora.

Spermophilus harrisi was described by Audubon and Bachman from a specimen from an unknown locality. It now becomes expedient to restrict the application of the name harrisi to the darker form, which was found on the Mexican boundary line, from the Santa Cruz Valley westward as far as the Sonoyta, where intergrades were taken at Quitovaquito. The tail, in seven specimens of S. harrisi from Tueson, Arizona, measured in the flesh by Mr. P. L. Jouy, averaged $76 \mathrm{~mm}$. in length.

\section{LEPUS MERRIAMI, new species.}

RIO GRANDE JACKRABBIT.

Lepus texianus, Audubon and Bachman, N. Am. Quad., III, p. 156, pl. exxxiii, 1853 (Texas).

Lepus callotis, BAIRD, Mamm. N. Am., p. 590, 1857 (in part only); U. S. and Mex. Bound. Surv., pp. 45 and 46, 1859 (in part only).-Allex, N. Am. Rodentia, p. 350,1877 ("Var. callotis," in part).

Type.-No. 2317 (Coll. International Boundary Commission). Adult female, from Fort Clark, Kinney County, Texas. Collected by Dr. Mearns, April 6, 1893. Similar to L. callotis, of Mexico, but with shorter ears, which are black instead of white at the tip; and the upper 
surface of the body inclines to grayish fawn-color rather than ochraceous buff.

This is the common "Jackrabbit" of the Rio Grande. It has been described by Audubon and Bachman, Baird, Allen, and other writers, under the preoccupied names of callotis and texianus, with which species it has been confounded.

PEROMYSCUS CANUS, new species.

TEXAS GRAY MOUSE.

Type.-No. $\frac{21109}{37096}$, U.S.N.M. (Coll. International Boundary Commission). Adult female, from Fort Clark, Kinney County, Texas. Collected by Dr. Mearns, January 13, 1893. Original number, 2208.

Description of type.-Above, drab gray, with a dark vertebral area, where the pelage is more thickly lined with black. Feet and under parts pure white; tail bicolored, blackish above, white below; ears and tail well clothed with hair; soles of feet densely pilose posteriorly; skull narrow, slender, and rectangular, with the brain-case low and elongated and the rostral portion long. Length, $175 \mathrm{~mm}$.; tail vertebræ, 75; ear from crown, 11.5 (small); hind foot, 21. Teats, $\frac{1-2}{1-2}$.

Remarks.-This mouse is quite similar in size and coloration to Peromyscus mearnsii, Allen, from which it may be readily distinguished by its smaller, more hairy, ears, and its much shorter, more hairy, and sharply bicolored tail, as well as by its longer fur at all seasons. The skull of $P$. mearnsii is smaller, and has a more swollen brain-case, shorter and more depressed rostrum, and shorter pterygoid fossa. Perhaps the dentition is also a little heavier. Compared with $P$. leucopus, the skull is lower and more slender, with a corresponding shortening of the brain-case, pterygoid fossa, and rostrum. Peromyscus texanus, a very distinct species, occurs with $P$. canus in portions of its range.

PEROMYSCUS TORNILLO, new species.

TORNILLO MOUSE.

Type.-No. $\frac{20025}{354 \frac{2}{0}}$, U.S.N.M. (Coll. International Boundary Commission). Adult male, from the Rio Grande, about 6 miles above El Paso, Texas. Collected by Edgar A. Mearns and Frank X. Holzner, February 18, 1892. Original number, 1458.

Description of type.-Upper parts light broccoli brown; ears and upper side of tail hair brown; feet and under parts pure white; body stout; ears and tail well haired, the latter sharply bicolored; soles densely pilose posteriorly. Length, $192 \mathrm{~mm}$; tail vertebræ, 90; ear above crown, 12 ; hind foot, 23.

The skull of this mouse is at once distinguished from all other Texan mice of this genus by its larger size. The animal bears superficial resemblance to the $P$. arizonce, recently described by Dr. J. A. Allen, 
from Fairbank, on the San Pedro River, Arizona. Externally it is distinguished from that species by its paler coloration, slightly smaller ears, and stouter body. The largest skulls of $P$. arizonce equal the average size of $P$.tornillo, but the shape differs considerably therefrom. In both, the rostral portion is long and high, this character sufficing to distinguish these species from sonoriensis and the other subspecies of Peromyscus texanus. The skull of $P$. tornillo is low and squarish, its zygomatic arches standing strongly out in front, as sharp elbows at right angles to the cranial axis.

\section{PEROMYSCUS TEXANUS MEDIUS, new subspecies. ${ }^{1}$}

\section{SAN DIEGO PLAINS-MOUSE.}

Between the ranges of the subspecies gambelii and thurberi, both dark-colored races of Peromyscus texanus, there is a narrow strip of southern and Lower California, bordering the Pacific Ocean for several hundred miles and extending east to the Coast Range of mountains, occupied by the present race, which differs from either of those above mentioned in being paler, with more drab and clay-colored tints. It is smaller than P.t. gambelii, with much larger ears, and a shorter tail. Its paler, more ochraceous coloration at once distinguishes it from $P$. $t$. thurberi, with which it agrees in size. From $P$. $t$. deserticola, of the interior deserts, it differs in being less robust, and in having somewhat larger ears, and much darker colors.

Type.-No. 61059, U.S.N.M. (Coll. International Boundary Commission). Adult male from Nachoguero Valley, Lower California. Collected by Dr. Mearns, June 4, 1894. Original number, 3623.

Description of type.-Above wood brown, shading to russet on cheeks and sides, thickly mixed with black, giving a dusky dorsal area; ears clove brown, densely clothed, with faint hoary edging; top of head wood brown, paler than back; feet and under parts pure white; tail black above, white on sides and below. Length, $160 \mathrm{~mm}$; tail vertebræ, 70; ear from crown, 17; hind foot, 21.

\section{PEROMYSCUS TEXANUS CLEMENTIS, new subspecies.}

\section{SAN CLEMENTE MOUSE.}

Forms of Peromyscus texanus have been collected on the Coronados Islands, and on Santa Rosa, Santa Catalina, and San Clemente, of the Santa Barbara group. Of these I have only examined those from

${ }^{3}$ For the species of mouse to which this subspecies and the next belong, the earliest name available is Hesperomys texanus, Woodhouse. Two of Dr. Woodhouse's specimers are still in the U.S. National Museum. One of these, the type, is alcoholic, and the other a skin. From these I have removed the skulls for examination. Baird's Hesperomys texanus is composite, four species of Peromyscus and an Onychomys having been included in his "list of specimens," as proven by specimens still extant. I have seen no evidence of intergradation between $P$. leucopus and the forms of $P$. texanus. 
Santa Rosa (2 specimens) and San Clemente Island (38 specimens, collected by myself and Mr. A. W. Anthony). The skins from Santa Rosa Island are referred to the mainland form (P.t. medius), though approaching $P$. t. clementis. This island race is mucb blacker than $P$. t. medius, with a stronger, more reddish coloration, except on the head, which is drab.

Type.-No. 61117, U.S.N.M. (Coll. International Boundary Commis sion). Adult male, from San Clemente Island, California. Collected by Dr. Mearns, August 27, 1894. Original number, 3819.

Description of type.-Above drab anteriorly, strongly tinged with burnt umber posteriorly; top of head, drab gray; ears black, with faint hoary edging; feet and under surface, white; tail sharply bicolored. Length, $177 \mathrm{~mm}$.; tail vertebræ, 77; ear, 17; hind foot, 21. 


\section{$2 \mathrm{BHL}$ Biodiversity Heritage Library}

Mearns, Edgar Alexander. 1896. "Preliminary diagnoses of new mammals from the Mexican border of the United States." Proceedings of the United States National Museum 18(1075), 443-447. https://doi.org/10.5479/si.00963801.1075.443.

View This Item Online: https://www.biodiversitylibrary.org/item/32799

DOI: https://doi.org/10.5479/si.00963801.1075.443

Permalink: https://www.biodiversitylibrary.org/partpdf/5718

\section{Holding Institution}

Smithsonian Libraries

\section{Sponsored by}

Smithsonian

\section{Copyright \& Reuse}

Copyright Status: NOT_IN_COPYRIGHT

This document was created from content at the Biodiversity Heritage Library, the world's largest open access digital library for biodiversity literature and archives. Visit BHL at https://www.biodiversitylibrary.org. 